\title{
A Leucistic Checkered Keelback, Fowlea piscator (Serpentes: Natricidae), from Mizoram, India
}

\author{
Khan Ashaharraza ${ }^{1}$, Lalbiakzuala ${ }^{2}$, and Hmar Tlawmte Lalremsanga ${ }^{2}$
} ${ }^{1}$ Department of Wildlife and Biodiversity Conservation, North Orissa University, Baripada-757003, Mayurbhanj, Odisha, India (ashaharrazakhan@gmail.com)
2Department of Zoology, Mizoram University, Aizawl-796004, Mizoram, India (htlrsa@yahoo.co.in)

$\mathrm{C}$ olor abnormalities in animals can occur as the result of an excess or deficiency of pigments in some parts or in the entire body. Albinism is a complete lack of pigmentation, whereas leucism is characterized by reduced integumentary pigmentation but normally-colored eyes (Acevedo and Aguayo 2008). Leucistic snakes have diminished numbers of iridophores and probably very low numbers or no melanophores and xanthophores (Bechtel 1991).

The Checkered Keelback (Fowlea piscator; formerly Xenochrophis piscator) is widely distributed throughout southern Asia (Wallach et al. 2014) and is perhaps the most abundant snake in India (Whitaker and Captain 2004). However, the taxonomy is not completely resolved and still cryptic species might be hidden under this name (Vogel and David 2012).

On 15 June 2019, we collected a leucistic juvenile Fowlea piscator from Tuivamit, Aizawl District, Mizoram (244' $51.36 " \mathrm{~N}$; 92040'86"E; $874 \mathrm{~m}$ asl). The specimen was preserved and deposited in the Departmental Museum of Zoology, Mizoram University, Aizawl (MZMU-1091;
Fig. 1). The snake lacked integumentary pigmentation, but the eyes were normally pigmented (Fig. 2). Although Mahabal and Takur (2014) and Deshmukh et al. (2020) previously reported albinistic or leucistic Checkered Keelbacks from peninsular India, this is the first report from northeastern India and the first record from the state of Mizoram.

\section{Acknowledgements}

We thank Liandawla (Chief Wildlife Warden, Environment, Forest and Climate Change Department, Government of Mizoram, India) for issuing collection permit No. A.33011/2/99-CWLW/225. We also thank DST-SERB, New Delhi, for providing financial assistance for laboratory facilities under EMR number EMR/2016/002391. KA extends his gratitude to Pratyush Mohapatra, Saipari Sailo (Central Zone Regional Center, Zoological Survey of India, Jabalpur), and Vivek Sharma for help with the literature and curatorial support, and to Zothangliana, Department of Zoology, Mizoram University, for help collecting the snake.
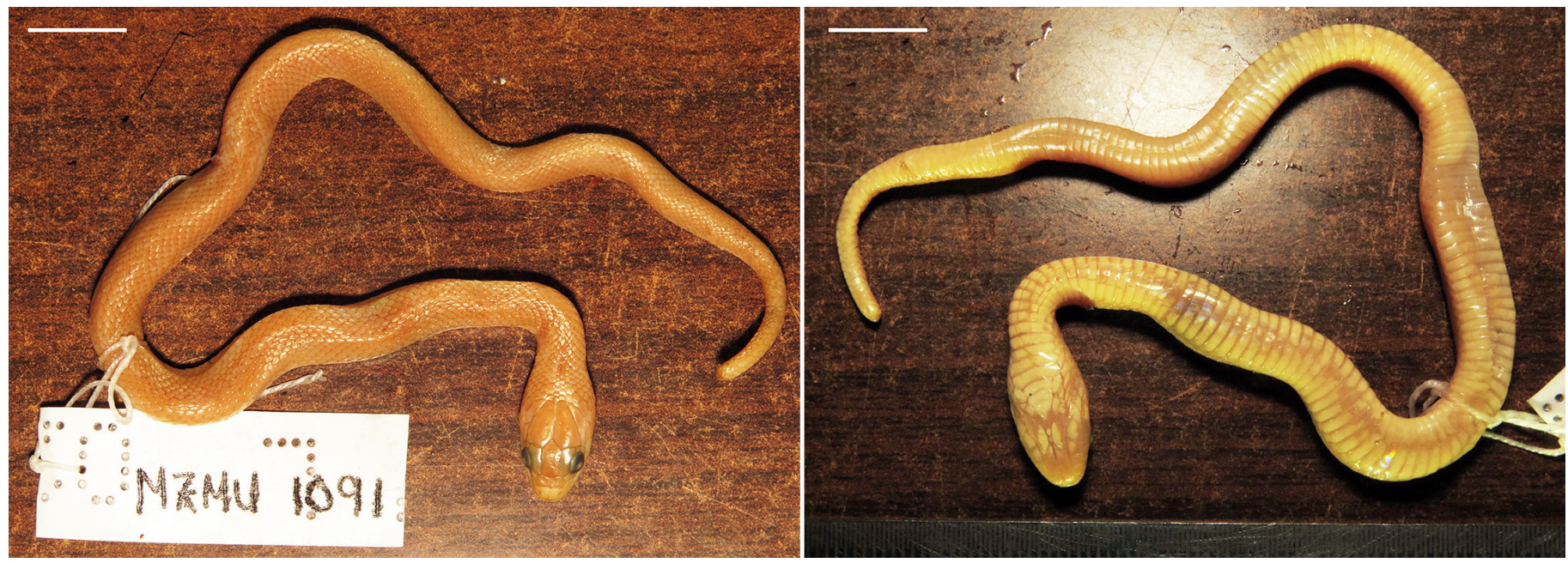

Fig. 1. A leucistic Checkered Keelback (Fowlea piscator, MZMU-1091) from Tuivamit, Mizoram, India. Scale bar = 10 mm. Photograph by Khan Ashaharraza. 

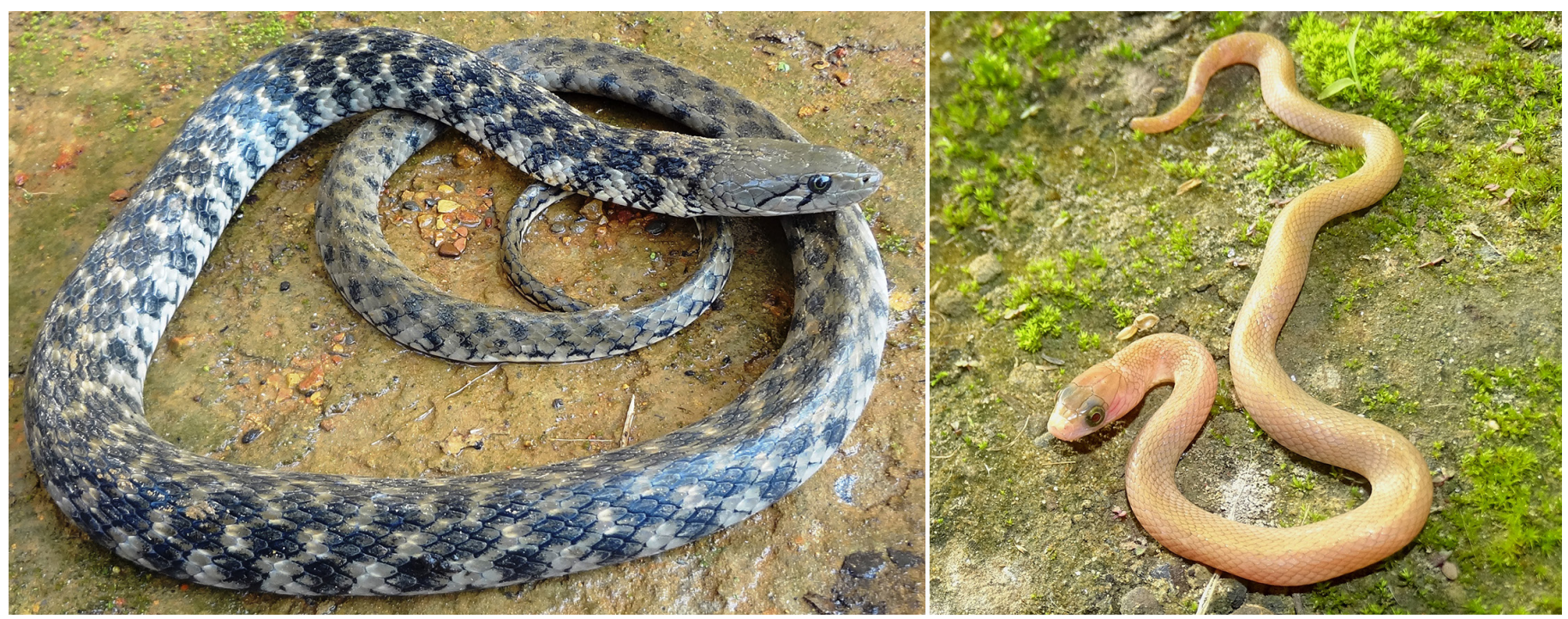

Fig. 2. A typically colored Checkered Keelback (Fowlea piscator) (left) and a leucistic individual (right) from Tuivamit, Mizoram, India. Photographs by Hmar Tlawmte Lalremsanga.

\section{Literature Cited}

Acevedo, J. and M. Aguayo. 2008. Leucistic South American sea lion in Chile, with a review of anomalously color in otariids. Registro en Chile de leucismo en lobo marino común, con una revisión de las coloraciones anormales en otáridos. Revista deBiología Marina y Oceanografia 43: 413-417.

Deshmukh, R.V., S.A. Deshmukh, S.A. Badhekar, J. Rewatkar, V.P. Pachare, and S.B. Kawale. 2020. First records of albinism or leucism in six species of snakes from central India. Reptiles \& Amphibians 26: 174-179.

Bechtel, H.B. 1991. Inherited color defects. Comparison between humans and snakes. International Journal of Dermatology 30: 243-246.

Mahabal, A. and S. Thakur. 2014. Instances of aberrant colors and patterns among the Indian herpetofauna: A review. Russian Journal of Herpetology 21: 80-88.

Vogel, G. and P. David. 2012. A revision of the species group of Xenochrophis piscator (Schneider, 1799) (Squamata: Natricidae). Zootaxa 3473: 1-60.

Wallach, V., K.L. Williams, and J. Boundy. 2014. Snakes of the World: A Catalogue of Living and Extinct Species. CRC Press, Boca Raton, Florida.

Whitaker, R. and A. Captain. 2004. Snakes of India. The Field Guide. Draco Books, Chennai, India. 